\title{
Kara śmierci jako aktualny dylemat w opinii mieszkańców Włocławka i okolic
}

\section{Death penalty as a current dilemma in opinion of Włocławek and environs society}

\section{Streszczenie:}

Przedmiotem artykułu jest stosunek mieszkańców Włocławka i okolic do problemu zasadności kary śmierci. Autorka odwołuje się do badań socjologów, filozofów oraz teologów i drobiazgowo rekonstruuje sam fenomen kary głównej. Omawia pokrótce jego historię, genezę, aspekty filozoficzne i religijne. Następnie ukazuje - na przykładzie samodzielnie przeprowadzonych badań (ankieta) - stosunek społeczeństwa Włocławka i okolic do problemu. Jednocześnie autorka zastanawia się, jakie czynniki mają zasadniczy wpływ na kształtowanie się poglądów człowieka dotyczących tej kwestii.

Słowa kluczowe: kara śmierci, opinia społeczna, Włocławek

\begin{abstract}
:
The subject of the article is an attitude of Włocławek society towards the death penalty issue. The author refers to sociological, philosophical and theological researches and reconstructs precisely the phenomenon of the capital punishment. She analyses its history, genesis, as well as philosophical and religious aspects. Furthermore she shows - using an example of her own research (questionnaire) - an attitude of Włocławek community towards the
\end{abstract}


Karolina Rożko - Kara śmierci jako aktualny dylemat...

problem. At the same time the author figures out which conditions influence on opinions in this particular matter.

Keywords: death penalty, social opinion, Włocławek

\section{Wprowadzenie}

Kara śmierci to odwieczny problem moralny, który ciągle wydaje się nierozstrzygnięty. Nawet obecnie, w XXI wieku, nie milkną dyskusje nad jej sensem. W krajach, gdzie jest stosowana, pojawiają się grupy protestujących, z kolei w krajach, gdzie nie obowiązuje, posiada ona swoich zagorzałych zwolenników. Polskie społeczeństwo również jest podzielone co do słuszności kary śmierci, jak i kształtu systemu penitencjarnego w ogóle. Kwestie sporne można dostrzec w poglądach prezentowanych przez mieszkańców Włocławka i okolic, o czym świadczy przeprowadzona ankieta.

Wzięło w niej udział 125 osób reprezentujących - z założenia różne przedziały wiekowe, różne płcie, grupy społeczne i wyznaniowe. Niestety nie wszyscy respondenci udzielili odpowiedzi na wszystkie zadawane pytania, co nieznacznie wpływa na precyzję badania, gdyż odsetek pytań wypełnionych okazuje się za każdym razem nieporównywalnie wyższy od ilości pytań pozostających bez odpowiedzi.

Najwięcej ankietowanych znalazło się $\mathrm{w}$ przedziale wiekowym między 18 a 24 rokiem życia (45\%), jedna trzecia (30\%) to osoby między 25 a 50 rokiem życia, nieco mniejszą grupę stanowią ludzie mający powyżej 50 lat (25\%), 27 uczestników badania nie udzieliło odpowiedzi na pytanie o wiek. $63 \%$ stanowiły kobiety, a 37\% mężczyźni, 23 osoby nie ujawniły swojej płci. 61\% (67 osób) wszystkich ankietowanych zamieszkuje w mieście, z kolei 39\% (43 os.) na wsi, jednak dane te nie uwzględniają 11\% osób, które nie odpowiedziały na to pytanie. 


\section{Krótka historia kary śmierci}

Refleksję nad karą śmierci trzeba zacząć od samej koncepcji kary. Jej przemiany odzwierciedlają metamorfozy w historii kultury. Jak wskazuje Jarosław Warylewski, zjawisko kary może wywodzić się z idei zemsty indywidualnej (np. ojca rodziny), czy też zemsty publicznej, która przemieniła się z czasem w karę kryminalną ${ }^{1}$. W społecznościach archaicznych sankcje śmiertelne posiadały charakter tzw. zemsty rodowej, która obligowała członków rodziny do pomszczenia krewniaka (w myśl idei prawa krwi), przy czym karze podlegał nie tylko sam winowajca, ale czasami też jego bliscy. Stopniowo wraz z kształtowaniem się systemu prawa kara śmierci zaczęła należeć do kompetencji władcy i nabierała charakteru sakralnego, stawała się ofiarą mającą załagodzić gniew bogów z powodu popełnienia zbrod$n i^{2}$.

Kolejnym etapem w ewolucji systemu penitencjarnego była zasada odwetu, „który ograniczał reakcję karną do kar odpowiadających czynowi sprawcy i jego skutkom"3, prowadził też do ograniczeń w wymierzaniu sprawiedliwości. Następnie pojawiła się forma okupu, który polegał na pieniężnej rekompensacie za popełnione czyny. Z czasem zaszły kolejne zmiany pod wpływem inspiracji dorobkiem prawnym świata starożytnego i średniowiecznego.

Upaństwowienie kary i odejście od systemu okupu dokonało się w okresie tzw. recepcji praw obcych. Wpływ prawa rzymskiego i kanonicznego doprowadził do przewartościowania dotychczasowej, prywatnej koncepcji przestępstwa i kary. Mnożące się przestępstwa przestały być traktowane wyłącznie jako czyny wymierzone w indywidualny interes jednostek, a zaczęto dostrzegać w nich elementy destabilizujące cały porządek prawny społeczeństwa 4 .

\footnotetext{
1 J. Warylewski, Kara. Podstawy filozoficzne i historyczne, Gdańsk 2007, s. 86.

2 M. Machinek MSF, Śmierć $w$ dyspozycji człowieka. Teologia moralna wobec problemów etycznych u kresu życia ludzkiego, Olsztyn 2001, s. 125-126.

3 J. Warylewski, dz. cyt., s. 87.

4 Tamże, s. 94.
} 
Karolina Rożko - Kara śmierci jako aktualny dylemat...

Wśród rozmaitych form penitencjarnych kara śmierci była najstarsza, wywodziła się z czasów starożytnych, funkcjonowała w prawie hetyckim, żydowskim, egipskim, rzymskim, w Kodeksie Hammurabiego i prawie Drakona5. Egzekucje miały charakter publiczny. Taka sytuacja trwała to w Europie do drugiej połowy XIX wieku, jednak dopiero sto lat później (czyli w drugiej połowie wieku XX) zaprzestano tych widowisk całkowicie. Do dzisiaj kara śmierci jest stosowana w formie „quasi-publicznej” w Stanach Zjednoczonych (dostępna tylko dla wybranych przedstawicieli społeczeństwa), z kolei spektakle śmierci $\mathrm{w}$ formie bliskiej czasom dawnym przetrwały $\mathrm{w}$ Chinach, Pakistanie, Libii, Arabii Saudyjskiej, Burundi i Gwinei6.

Wiązało się to z chęcią odstraszenia potencjalnych przestępców i skanalizowaniem niechęci lub frustracji społeczeństwa, które po obejrzeniu egzekucji skazańców niczym widowiska teatralnego pełnego przemocy, brutalności i bólu, mogło rozładować emocje i czuć się bezpieczniej. Skazaniec stawał się kozłem ofiarnym, wraz z jego śmiercią wszelkie problemy i poczucie zagrożenia odchodziły w niepamięć.

Stopniowo zaczęto odróżniać „zwyczajną” karę śmierci od „kwalifikowanej” lub „podwójnej” kary śmierci charakteryzującej się szczególnymi cechami, polegającej na wymyślnym zadawaniu bólu fizycznego i na psychicznym dręczeniu skazańca ${ }^{7}$. Zwyczajne rodzaje egzekucji to ścięcie głowy, powieszenie, a w wypadku żołnierzy rozstrzelanie. Z kolei kwalifikowana kara śmierci składała się z form dużo bardziej złożonych, zawierała szereg działań przed straceniem człowieka i po wykonaniu wyroku, takich jak: udręczenie skazańca w drodze na miejsce kaźni, bezczeszczenie zwłok ${ }^{8}$. Również na miejscu egzekucji skazany poddawany był rozmaitym torturom. Współcześnie w żad-

\footnotetext{
5 Tamże, s. 125.

6 Tamże, s. 126.

7 Tamże.

8 Tamże.
} 
nym z krajów uznawanych za cywilizowane krajów nie praktykuje się kwalifikowanych egzekucji ${ }^{9}$.

Obecnie na świecie wyraźnie odchodzi się od kary śmierci, o czym świadczą następujące dane przytoczone przez badacza ${ }^{10}$.

Rys. 1. Występowanie kary śmierci na świecie w czasach współczesnych

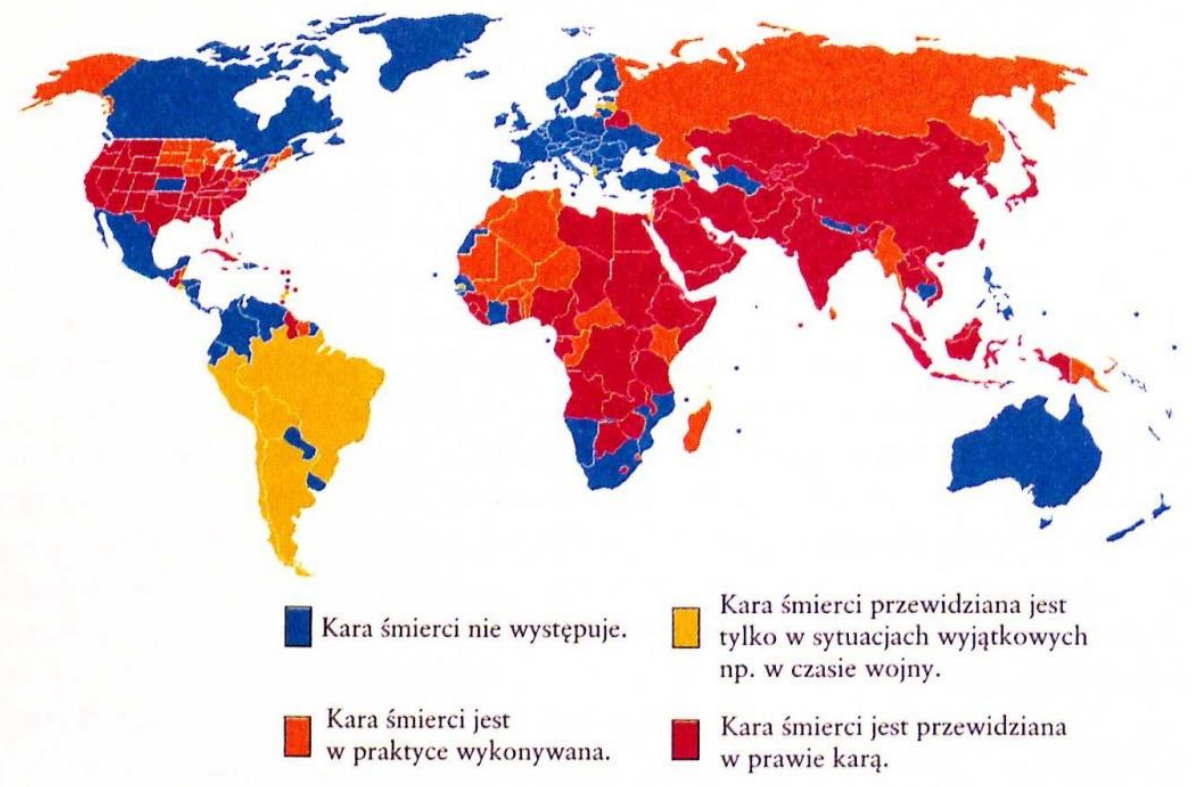

Źródło: J. Warylewski, Kara. Podstawy filozoficzne i historyczne, Gdańsk 2007, s. 128.

\section{Filozoficzne problemy kary śmierci}

Już Platon, ojciec greckiej filozofii idealistycznej, podkreślał ważność problemu zbrodni i kary. Zdaniem autora Państwa i Praw kara powinna być przede wszystkim sprawiedliwa, a osoba na nią skazana

9 Tamże, s. 127.

10 Tamże. 
Karolina Rożko - Kara śmierci jako aktualny dylemat...

ma stać się lepszą przez ból i cierpienie, a zarazem ma się stać przestrogą dla innych obywateli państwa ${ }^{11}$. W tym samym duchu filozof uzasadniał istnienie i sens kary śmierci - miała ona odstraszać potencjalnych zbrodniarzy, a poza tym widział w niej instrument do oczyszczenia kraju. Imię straceńca miała pokryć niepamięć, egzekucja winna stanowić pożytek dla innych, odstręczając od chęci czynienia zła, z kolei ciało należało wydalić poza granice państwa12.

Należy też wspomnieć o uczniu Platona, Arystotelesie, który dopuszczał karę śmierci na gruncie swojej filozofii prawa, zakładając, że istnieją pewne rodzaje przestępstw, co do których kara ostateczna może być „jedynie adekwatną czy też proporcjonalną karą"13. Podobnie usprawiedliwiał najwyższy z możliwych wymiar kary Seneka, filozof rzymski reprezentujący stoicyzm ${ }^{14}$. Śmierć nie była dla niego ani złem, ani dobrem, lecz kara śmierci - odpowiednio wykonana - mogła być środkiem leczącym o różnej mocy w wypadku skrajnej demoralizacji jednostki.

Problematyczne okazuje się ujęcie kary śmierci w kulturze judeochrześcijańskiej. Z jednej strony Stary Testament przewidywał ten rodzaj kary za wiele przewinień, takich jak zabójstwo, cudzołóstwo, bluźnierstwo ${ }^{15}$, znieważenie rodziców, z drugiej zaś w Nowym Testamencie - choć nie ma mowy o kwestionowaniu tejże kary - nie można też wskazać fragmentów jednoznacznie ją akceptujących ${ }^{16}$. Przykładem takiej niejednoznaczności są interpretacje listów Świętego Pawła17. Wyraźnie dystansowali się od kary śmierci Ojcowie Kościoła tacy jak Tertulian, czy Atenagoras ${ }^{18}$. Święty Augustyn, choć również

11 Tamże, s. 35-36. Zob. także B. Bartusiak, Kara śmierci w świetle sporu o racjonalizację kary, Warszawa 2011, s. 5.

12 B. Bartusiak, dz. cyt., s. 7-8.

13 Tamże, s. 18.

${ }^{14}$ M. Machinek, dz. cyt., s. 126.

15 B. Hernik-Pikulska, Kara śmierci. Studium socjologiczne, Kraków 2006, s. 45-50.

16 M. Machinek, tamże.

17 Tamże, s. 126-127. Zob. także T. Ślipko SJ, Kara śmierci z teologicznego i filozoficznego punktu widzenia, Kraków 2000, s. 18-25.

18 M. Machinek, s. 127. 
nie odbierał władzy państwowej prawa do karania śmiercią, ani nie dostrzegał w tym sprzeczności z piątym przykazaniem Dekalogu, opowiadał się za odstąpieniem od niej ze względu na dobroć Chrystusa ${ }^{19}$. W czasach średniowiecza sytuacja nie ulegała zmianie - Kościół nie domagając się rozlewu krwi oddał zupełnie prawo do karania śmiercią państwu, czego przykładem może być myśl Świętego Tomasza z Akwinu20.

Przełom w myśleniu o karze śmierci dokonał się dopiero w czasach nowożytnych. Filozof i prawnik Cesare Beccaria kierujący się ideami oświeceniowymi, w tym humanitaryzmem, zaprezentował niezwykle postępowy punkt widzenia. Uważał, że celem kary nie jest torturowanie przestępcy, ani też unieważnienie jego czynu, lecz przeszkodzenie winnemu w wyrządzaniu nowych szkód obywatelom i powstrzymanie innych od naśladowania tego typu przestępstw21. Zdaniem Beccarii kara śmierci, choć znana od stuleci, nigdy nie odstraszała potencjalnych przestępców, gdyż człowiek z natury jest bardziej podatny na bodźce długotrwałe i uciążliwe niż wstrząsające ale krótkie - jakimi są publiczne egzekucje.

Nie surowość lecz długotrwałość kary wywiera największe wrażenie na duszę człowieka, gdyż na naszą wrażliwość łatwiej i trwalej wpływają wrażenia nawet najsłabsze, ale za to powtarzające się, aniżeli wstrząsy silne, lecz przemijające. [...] Najmocniejszym hamulcem powstrzymującym od popełniania przestępstw jest nie przerażające choć przejściowe widowisko śmierci złoczyńcy, lecz długotrwały i pełen cierpień przykład człowieka, który postradawszy wolność, stał się zwierzęciem roboczym i swym trudem wynagradza krzywdę wyrządzoną społeczeństwu22.

Kara śmierci wedle Bekariusza jako widowisko wywołujące współczucie i oburzenie zamiast zbawienne przerażenie nie pełni funkcji

19 Tamże.

20 Tamże, s. 128. Zob. także T. Ślipko, dz. cyt., s. 49-51.

21 C. Beccaria, O przestępstwach i karach, z VI wydania oryginału (1766) przełożył, wstępem, przedmową, wykazem literatury i przypisami opatrzył dr Emil Stanisław Rappaport, profesor zwyczajny Uniwersytetu Łódzkiego, Warszawa 1959, s. 88.

22 Tamże, s. 145. 
Karolina Rożko - Kara śmierci jako aktualny dylemat...

odstraszenia przestępców ${ }^{23}$. Ponadto Beccaria wskazywał też na wątpliwości natury moralnej, gdyż człowiek nie może być panem swojego życia. Prawo zadawania śmierci nie jest - jak prawo ustawodawcze wyrazem poszczególnych wolności obywatelskich do kreowania rzeczywistości społecznej, ale raczej wolność odbiera ${ }^{24}$. Poglądom Bekariusza sprzeciwiały się takie autorytety filozoficzne jak Immanuel Kant Georg Wilhelm Friedrich Hegel. Był to ważny głos rozpoczynający dyskusję nad istotnością kary śmierci, prowadzący do wzrostu zainteresowania nienaruszalnymi prawami człowieka, czego wynikiem była Europejska Konwencja Praw Człowieka znosząca karę śmierci w roku $1983^{25}$.

\section{Aspekty religijne kary głównej}

Kościół Rzymskokatolicki zdecydowanie sprzeciwia się karze śmierci jako niezgodnej z podstawowymi założeniami dogmatyki i społecznej nauki chrześcijaństwa, czego wyraz stanowi głos Jana Pawła II wyrażony w encyklice Evangelium vitae ${ }^{26}$. Przede wszystkim należy zwrócić uwagę na antropologię chrześcijańską opartą na założeniach filozofii personalizmu chrześcijańskiego ${ }^{27}$. W myśl założeń tego nurtu każdy człowiek jest osobą i w związku z tym - jako dziecko Boże - posiada niezaprzeczalną i niemożliwą do odebrania godność człowieka wynikającą $\mathrm{z}$ samej racji istnienia. Nawet złoczyńca, który dopuścił się najcięższych zbrodni i nie wykazuje skruchy ani chęci poprawy, posiada tę godność i żaden człowiek, żadne prawo, ani nawet żaden wyrok sądowy nie może mu jej odebrać. Wobec tego nikt nie może poczuwać się władnym do odbierania jakiemukolwiek człowiekowi życia - jako niezbywalnego prawa i daru Bożego.

23 Tamże, s. 146.

24 Tamże, s. 142-143.

25 M. Machinek, s. 128.

26 Tamże, s. 135-136. Zob. także T. Ślipko SJ, dz. cyt., s. 9-16, 69-87.

27 Zob. E. Mounier, Ogólna idea osoby, [w:] Kierunki filozofii współczesnej, część I, red. J. Pawlak, Toruń 1995, s. 220-241. 
Ktokolwiek stawiałby się $\mathrm{w}$ pozycji uprawnionej do decydowania o ludzkim życiu, szargałby własną godność dziecka Bożego. Ludzkie życie jest wartością autoteliczną i niepowtarzalną, osoba ludzka bez względu na swoje cechy czy czyny, jakich dokonała, okazuje się więc nie do zastąpienia. Nie istnieją więc żadne obiektywne racje usprawiedliwiające zabicie człowieka w majestacie prawa. Jan Paweł II twierdził, że wraz z rozwojem systemu penitencjarnego przypadki, w których jednostka nawet po uwięzieniu pozostaje groźna dla społeczeństwa czy państwa, stają się wyjątkami niezwykle rzadkimi. Papież bardzo często apelował o niewykonywanie wyroków śmierci, przez co dawał przykład wcielania idei uniepotrzebnienia kary śmierci.

Ważnym elementem aspektu religijnego kary śmierci okazuje się także problem pokuty. Odebranie jednostce życia okazuje się wymuszeniem pokuty i zadośćuczynienia przez państwo na jednostce. Tymczasem w myśl dogmatów kościelnych kara może nabrać wymiaru pokutnego dopiero gdy zostanie przez skazańca zaakceptowana i świadomie oraz w sposób nieprzymuszony przyjęta ${ }^{28}$. Ponadto dyskusyjny wydaje się wpływ dogmatów soteriologicznych. W myśl teorii zbawienia chrześcijańskiego „odkupienie dokonane przez Chrystusa stanowi całkowitą i wystarczającą zapłatę za wszystkie grzechy ludzkości"29.

\section{Mieszkańcy Włocławka i okolic wobec kary śmierci. Wnioski z badań}

Powyższe aspekty bywają wykorzystywane zarówno przez retencjonistów, jak i abolicjonistów wiodących ze sobą ciągła dyskusję na temat zasadności i skuteczności kary głównej. Niezwykle ciekawym zagadnieniem wydaje się, jak wszystkie te kwestie odzwierciedlają się w odbiorze społeczności Włocławka i okolic.

\footnotetext{
28Tamże, s. 131.

29 Tamże.
} 
Karolina Rożko - Kara śmierci jako aktualny dylemat...

Swoje wykształcenie określiło 120 ze 125 badanych. Największą grupę $\mathrm{w}$ tym gronie stanowią osoby $\mathrm{z}$ wyższym wykształceniem 37\% (46 os.), niemalże tyle samo - 36\% (45 os.) stanowi odsetek z wykształceniem średnim. Następną, stosunkowo liczną grupą są respondenci posiadający wykształcenie gimnazjalne 21\% (26 os.), zaś zaledwie $2 \%$ (3 os.) udzielających odpowiedzi posiada jedynie wykształcenie podstawowe.

Wykres 1. Wykształcenie mieszkańców Włocławka i okolic

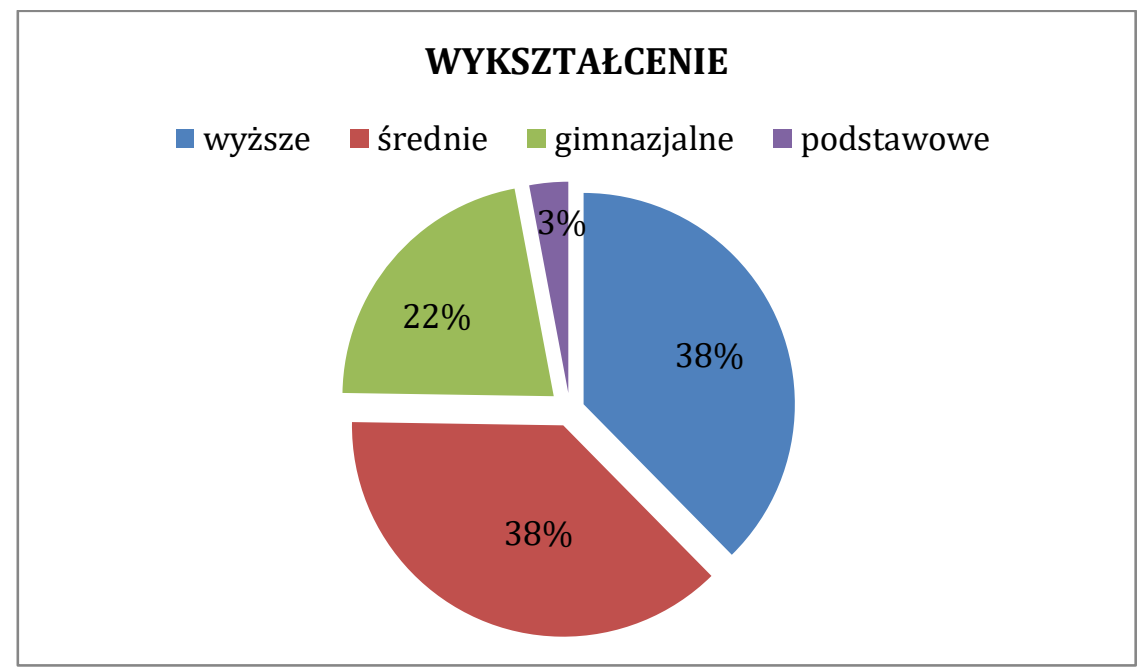

Źródło: badania własne.

Jednym z badanych aspektem były przekonania dotyczące źródeł przestępczości. Zdecydowana większość respondentów wyznaje przekonanie, że to wpływ środowiska popycha ludzi do łamania prawa i czynienia zła - 40\% (48 osób) ze 120, które odpowiedziały na to pytanie. Następna często zaznaczana odpowiedź zakłada, że przestępstwo posiada źródła w atmosferze domowej i wychowaniu człowieka - 20\% (24 os.). Ponadto 13\% (15 os.) uznaje sytuację ekonomiczną za czynnik prowadzący do łamania prawa. Wynika z tego, że niemal $3 / 4$ ankietowanych (73\%) wierzy w społeczne oddziaływanie na jedno- 
stkę, odrzuca „mityczne” przekonanie o genetycznym pochodzeniu przestępstw. W porównaniu z tymi wynikami należy zauważyć, że zaledwie 13\% (15 os.) twierdzi, że człowiek jest z natury skłonny do zła, a tylko 7\% (8 os.) utrzymuje, że skłonność do zła jest dziedziczna, Podobnie tylko 8\% (10 os.) wierzy, że przestępca pozostaje złoczyńcą do końca życia.

Wykres 2. Źródła przestępczości (w opinii ankietowanych)

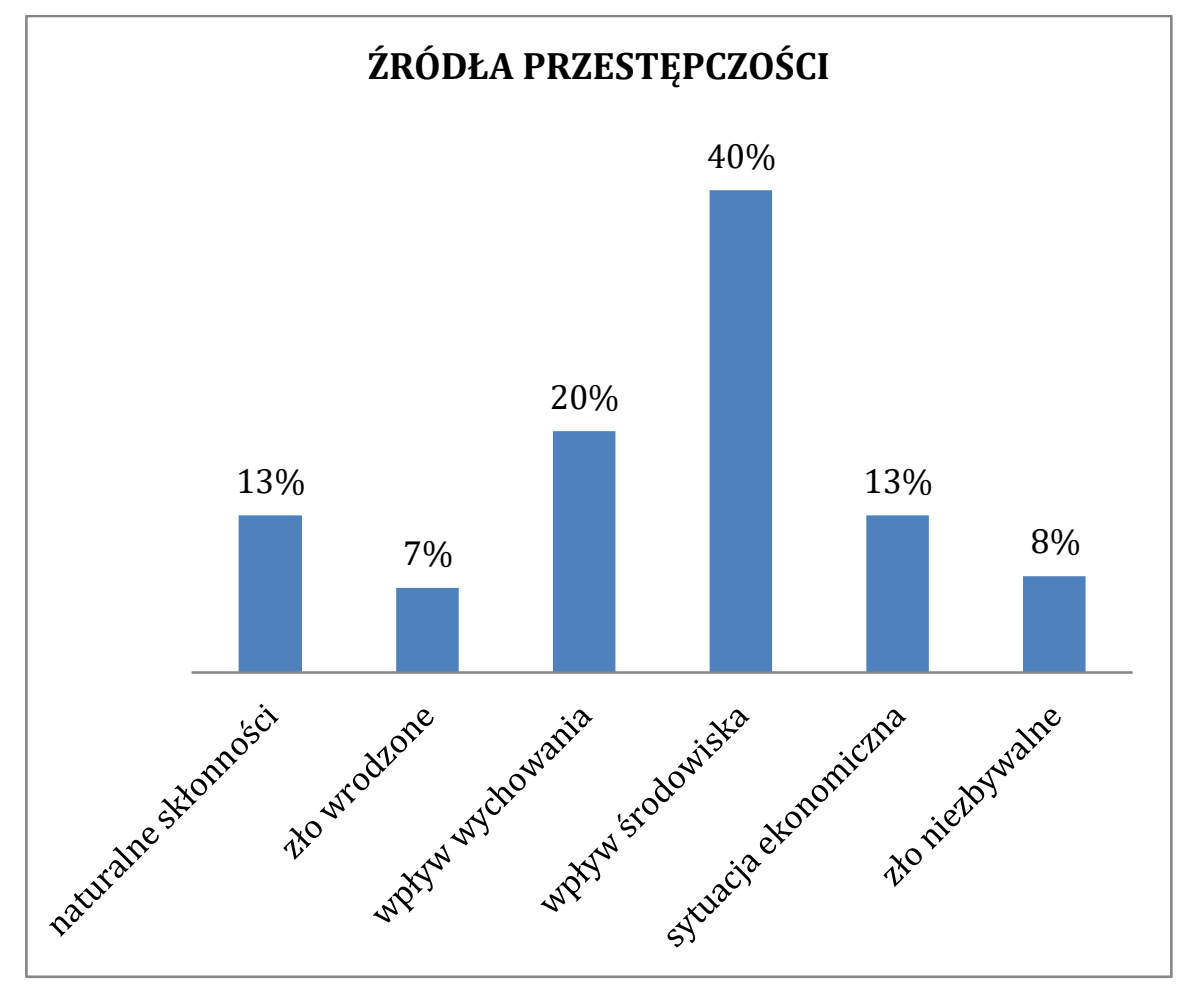

Źródło: badania własne.

Ankietowani okazali się również w przeważającej mierze osobami wierzącymi - 75\% zadeklarowało wiarę w Boga. Jedna czwarta - nie. 
Karolina Rożko - Kara śmierci jako aktualny dylemat...

Wykres 3. Deklaracja wiary (w opinii badanych)

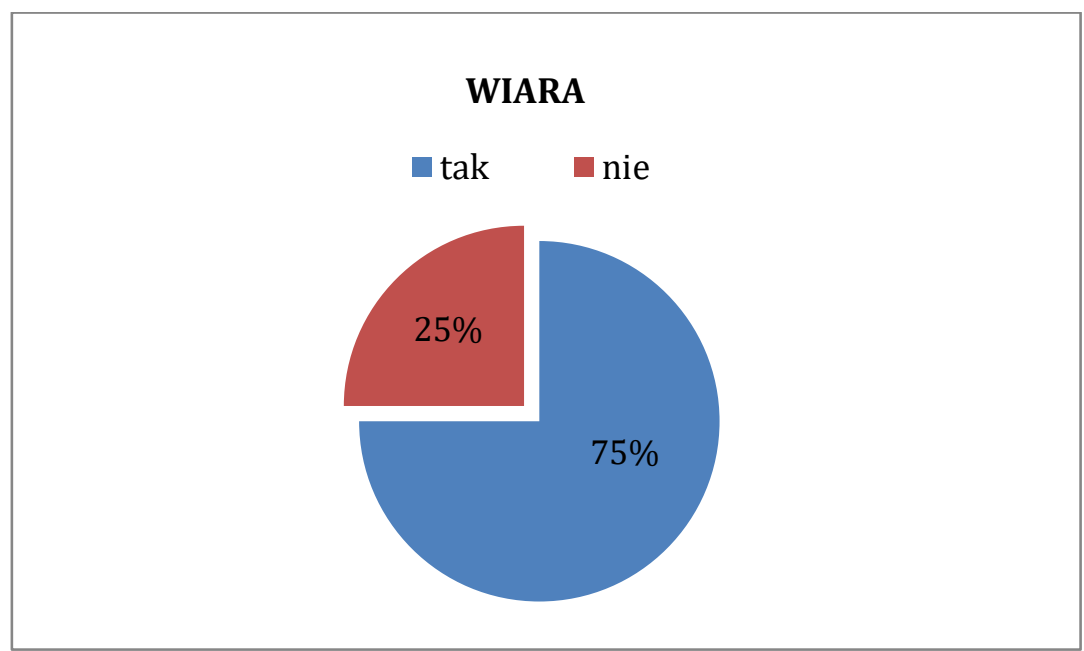

Źródło: badania własne.

Wykres 4. Deklarowane wyznanie badanych

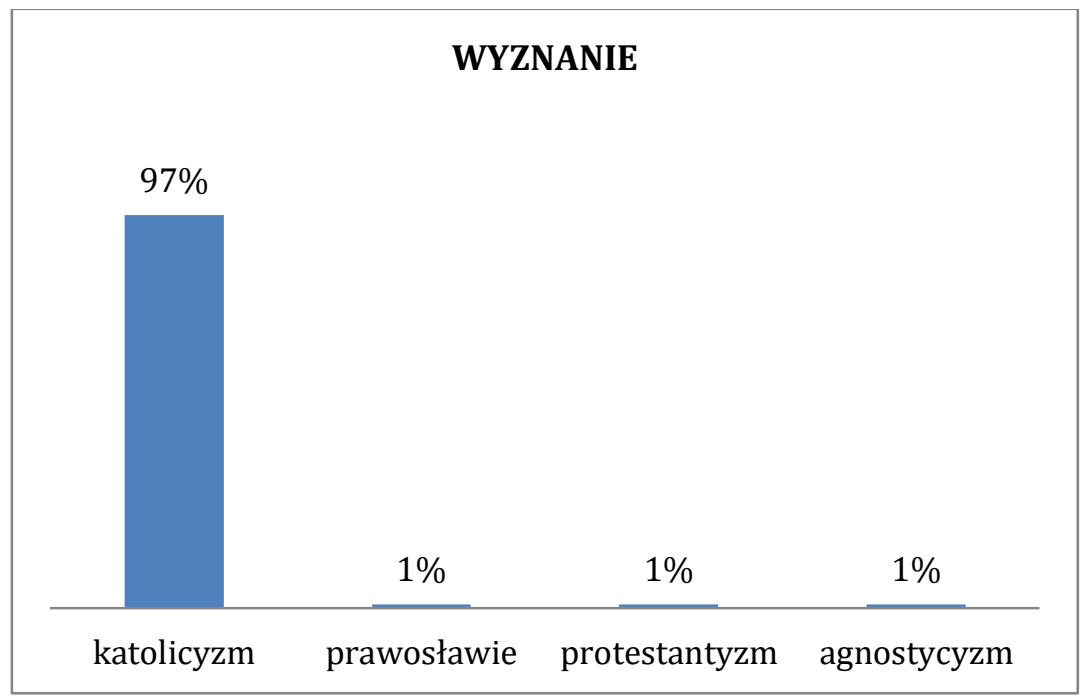

Źródło: badania własne. 
Wśród osób wierzących przeważają wyznawcy religii katolickiej 97\% (87 os.), poza tym 1 osoba zadeklarowała wyznanie prawosławne, 1 os. protestanckie, ponadto jedna osoba określiła się jako agnostyk.

Niezwykle ciekawe wyniki prezentuje pytanie dotyczące związku między wyznawaną religią, a dopuszczalnością kary śmierci. 24\% (27 os.) stwierdziło, że kara główna jest dopuszczalna zgodnie $\mathrm{z}$ ich wyznaniem, choć - jak łatwi policzyć - muszą to być osoby deklarujące przynależność do Kościoła Katolickiego. Można zastanawiać się, na ile ten wynik wiąże się z niewiedzą, z niedostateczną znajomością Katechizmu Kościoła i jego społecznego nauczania, a na ile manifestuje się w tym przypadku nowoczesna tendencja do wybierania sobie przez wiernych tych elementów religii, które sami uznają za słuszne. Jest to nowy typ religijności współczesnej, który wynika z dużej mierze z rozwiniętego indywidualizmu.

Wykres 5. Dopuszczalność kary głównej względem religii

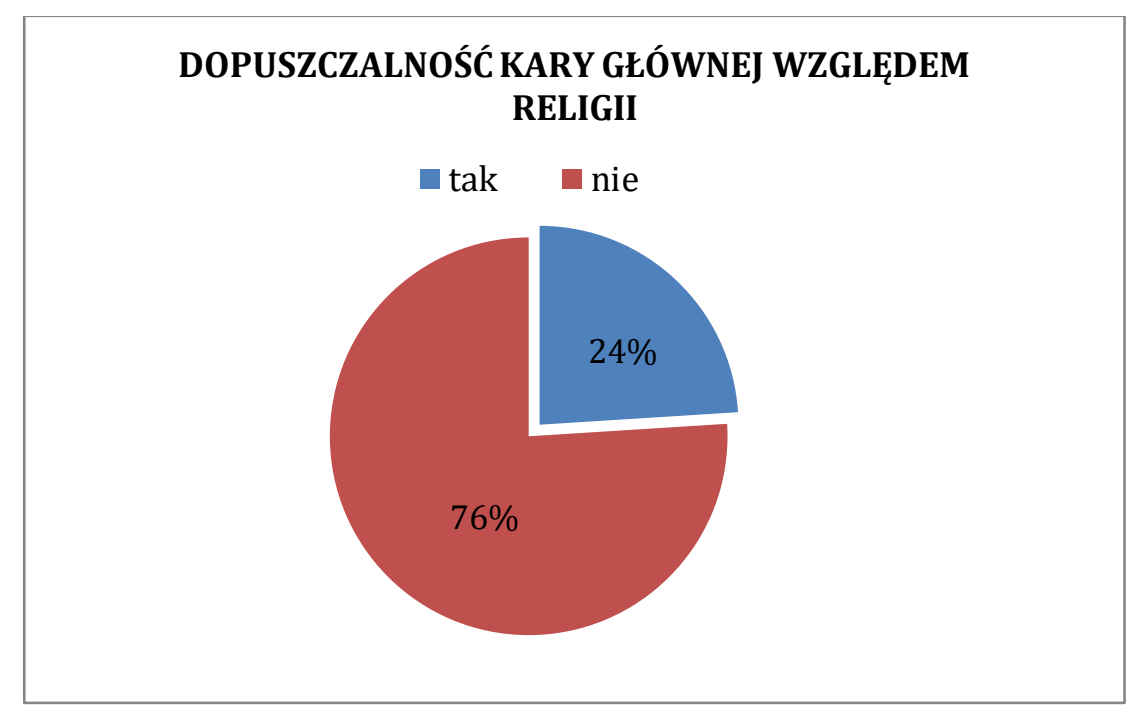

Źródło: badania własne. 
Karolina Rożko - Kara śmierci jako aktualny dylemat...

Kluczowym pytaniem dla badań jest kwestia potrzeby powrotu kary śmierci w Polsce. Większość - 57\% (70 os.) prezentuje się jako zwolennicy kary śmierci, natomiast przeciwnicy stanowią 43\% (53 osoby).

Wykres 6. Dopuszczalność kary głównej względem religii

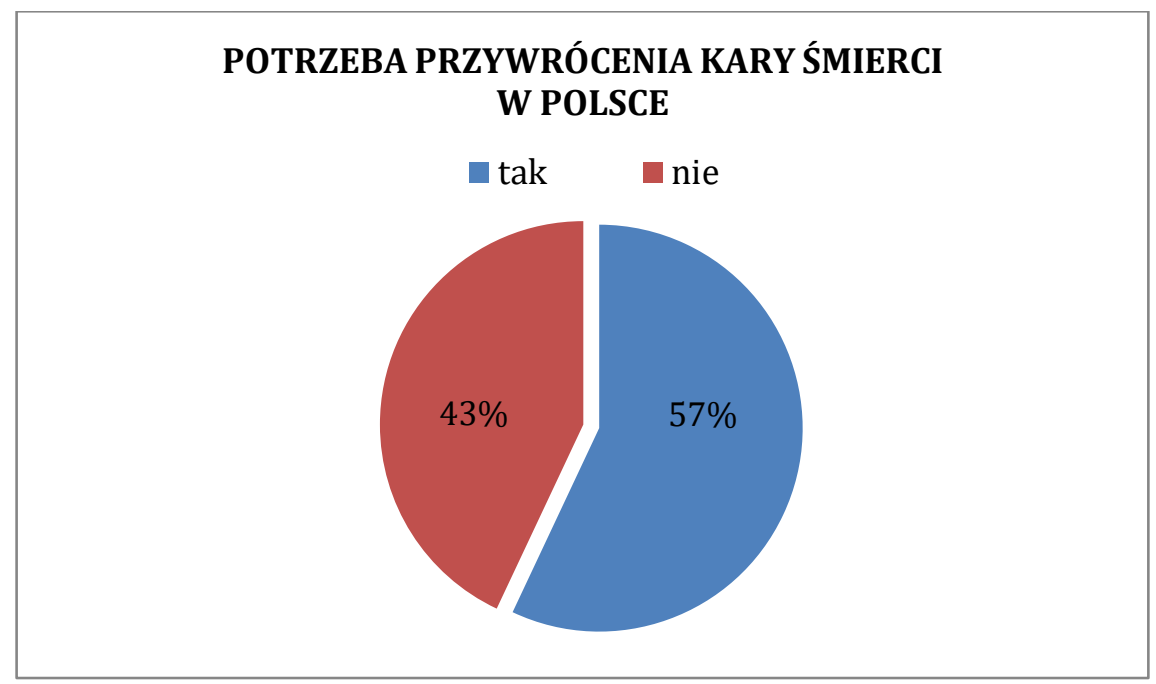

Źródło: badania własne.

Odpowiedzi udzieliły 123 osoby. Jeśli chodzi o wyniki to trend ten zdaje się odpowiadać ogólnopolskim tendencjom, które przedstawiał m.in. Jarosław Warylewski, powołując się na badania OBOP30. Prezentowane tutaj badania pokazują, że mieszkańcy Włocławka i okolic są raczej zwolennikami kary śmierci, choć dysproporcja między nimi, a przeciwnikami zaostrzenia prawa nie jest tak duża, jak w odniesięniu do wyników ogólnopolskich.

Następne pytanie dotyczyło problemu winy, która powinna być karana $\mathrm{w}$ najostrzejszy $\mathrm{z}$ możliwych sposobów. Respondenci mogli zaznaczyć więcej niż jedną odpowiedź. Ta część ankiety była wypeł-

30 J. Warylewski, dz. cyt., s. 135. 
niana tylko przez zwolenników przywrócenia kary śmierci (70 osób). Częstotliwość wyboru konkretnego przestępstwa przedstawia poniższy diagram. Najczęściej wybieranym przestępstwem okazało się zabójstwo ze szczególnym okrucieństwem, którą to możliwość zaznaczyło $80 \%$ badanych, na drugim miejscu znalazło się dzieciobójstwo, dopiero za nim ludobójstwo i inne.

Spośród zwolenników kary śmierci zdecydowana większość opowiedziała się za zastrzykiem z trucizną jako jej formą, która powinna obowiązywać - 67\% (44 os.). Mniej ankietowanych - 11\% (7 os.) wskazało na komorę gazową, 9\% (6 os.) - na krzesło elektryczne i powieszenie, a 5\% (3) - na rozstrzelanie. Wyniki te świadczą o próbie humanitarnego podejścia do skazańców, gdyż właśnie śmiertelny zastrzyk uważany jest obecnie za najbardziej humanitarną metodę wymierzania kary głównej.

Wykres 7. Forma egzekucji kary śmierci (w opinii badanych)

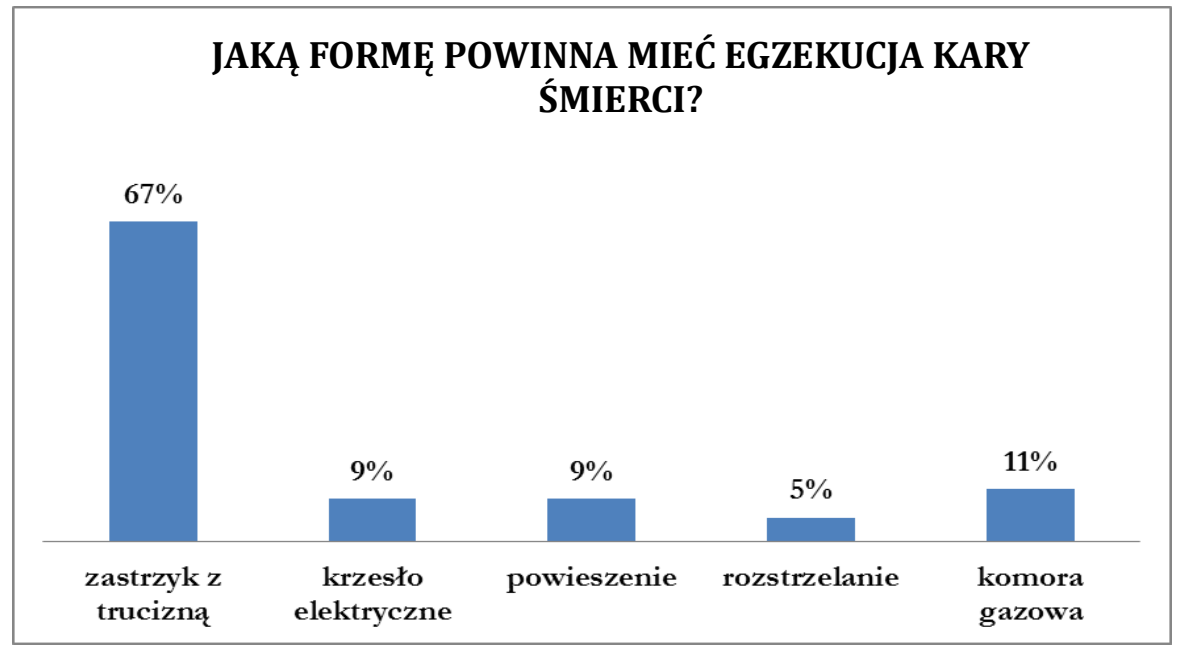

Źródło: badania własne. 
Karolina Rożko - Kara śmierci jako aktualny dylemat...

Jednocześnie tylko 28\% respondentów (19 os.) popierających karę śmierci uznało, że stracony powinien mieć możliwość wyboru egzekucji. Zdecydowana większość (72\%, 49 os.) była temu przeciwna.

Wśród zwolenników kary śmierci nadal wyraźnie panuje przekonanie, że śmierć pozostaje kwestią tabu w społeczeństwie i w związku z tym egzekucje nie powinny mieć charakteru publicznego - twierdzi tak $82 \%$ (55 os.). Pozwala to przypuszczać, że dla tych przedstawicieli społeczeństwa egzekucje publiczne nie mają charakteru odstraszającego, prewencyjnego widowiska, które należałoby np. pokazywać w mediach. Zaledwie 18\% (12 os.) posiada inne zdanie na ten temat.

Wykres 8. Odpowiedzialność karna (kara śmierci)

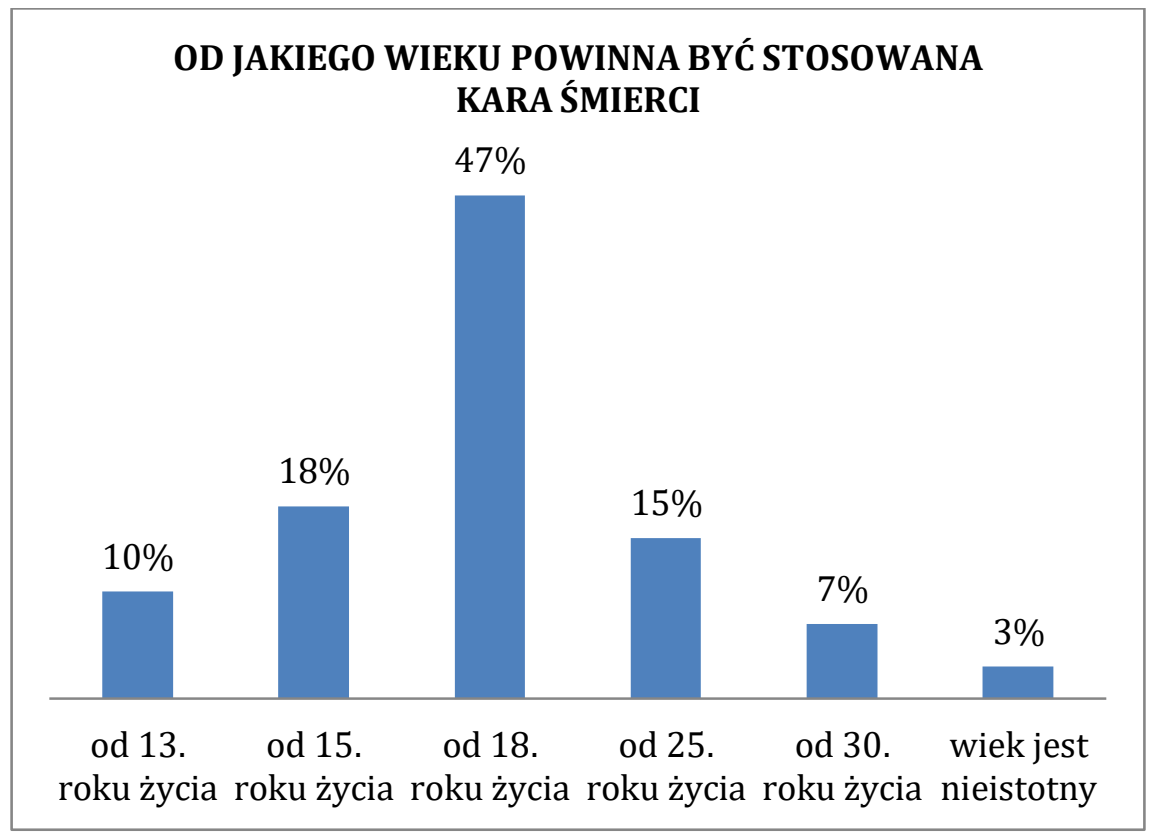

Źródło: badania własne.

Dyskusyjnym aspektem sporu wokół kary głównej okazuje się także wiek, od którego kara ta powinna obowiązywać. 10\% (7 os.) badanych uważa, że karę śmierci należałoby stosować od 13. roku 
życia. 18\% (12 os.) twierdzi, że skazany na śmierć powinien mieć minimum 15 lat. Zdecydowanie największą popularność osiągnęła odpowiedź „od 18. roku życia” - wybrało ją 47\% ankietowanych (32 os.). Mniej zwolenników zgromadziła opcja proponująca karę śmierci od 25. roku życia - 15\% (10 os.), dwukrotnie mniej ankietowanych 7\% (5 os.) - wybrało 30 roku życia. Dwóch respondentów (3\%) stwierdziło, udzielając otwartej odpowiedzi, że wiek nie jest kryterium istotnym, liczy się czyn wymagający kary.

Ciekawych wniosków dostarczają dane opisujące odpowiedzi na pytanie o cel kary śmierci. Blisko połowa badanych (47\%, 32 os.) uważa, że podstawowym celem takiej kary jest odstraszenie potencjalnego przestępcy. Następnym w kolejności, pod względem liczby oddanych głosów, wskazaniem jest skierowanie uwagi na tzw. potrzebę instytucjonalnej zemsty („zadanie przestępcy takiego samego cierpienia, jakie on spowodował ofierze) - takiego celu kary śmierci upatruje 32\% badanych (22 os.). 14 respondentów (21\% og.) stwierdza, że poprzez karę śmierci chodzi o eliminację niebezpiecznych jednostek i zmniejszenie zagrożenia społecznego.

Wykres 9. Cel kary śmierci w opinii badanych

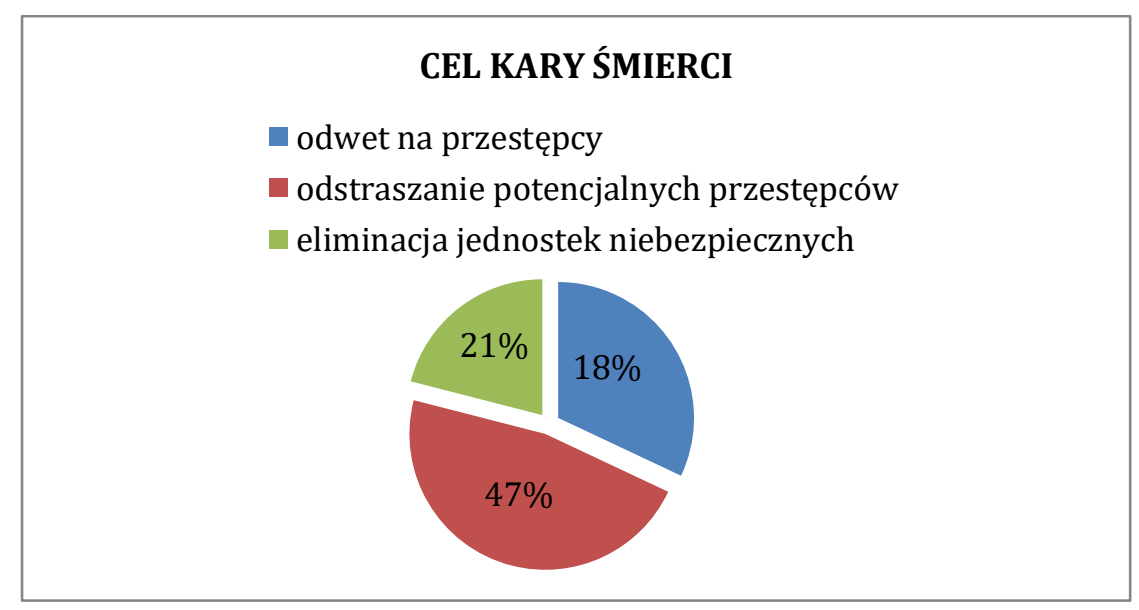

Źródło: badania własne. 
Karolina Rożko - Kara śmierci jako aktualny dylemat...

Wyniki te świadczą, że w świadomości społeczeństwa Włocławka i okolic kara śmierci, gdyby została ewentualnie przywrócona, powinna przede wszystkim pełnić funkcje prewencyjno-wychowawczą uważa tak bowiem $68 \%$ zwolenników. Nie zmienia to nadal faktu, że dla 1/3 ankietowanych kara główna miałaby być narzędziem zemsty wymierzanej przestępcy przez społeczeństwo, sposobem na instytucjonalne stosowanie przemocy, która należałoby odpłacać za zbrodnie.

By pełniej opisać badane opinie, warto poddać analizie niektóre zmienne niezależne. Pierwszą z nich jest wiek. W przedziale wiekowym 18-24 lata 28 osób zadeklarowało poparcie dla kary śmierci, przeciwko było 25 , co stanowi odpowiednio 53\% zwolenników i $47 \%$ przeciwników.

Wykres 10. Poparcie dla kary śmierci wśród badanych w wieku 18-24 lata

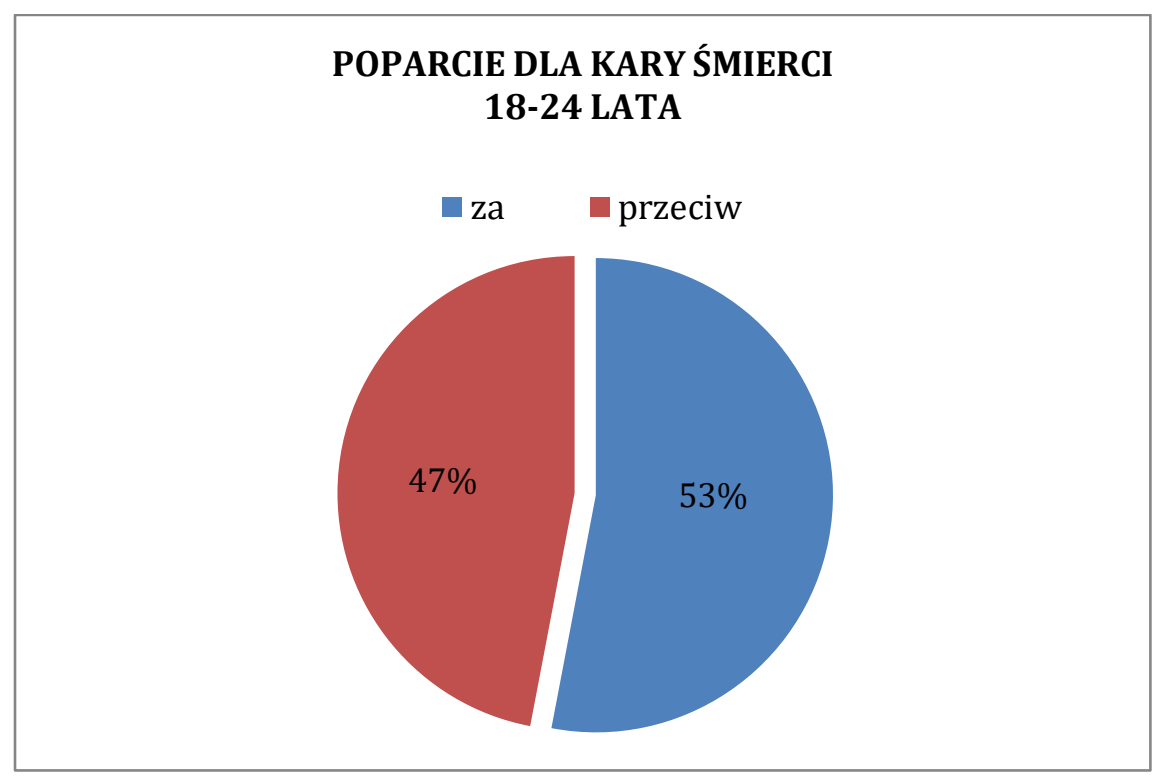

Źródło: badania własne. 
Tendencja ta utrzymuje się również w kolejnym przedziale (25-50 lat), gdzie wartości kształtowały się na poziomie 54\% „za” karą śmierci (19 osób) i 43\% „przeciw” (15 os.); 1 osoba (3\%) nie podała odpowiedzi.

Wykres 11. Poparcie dla kary śmierci wśród badanych w wieku 25-50 lat

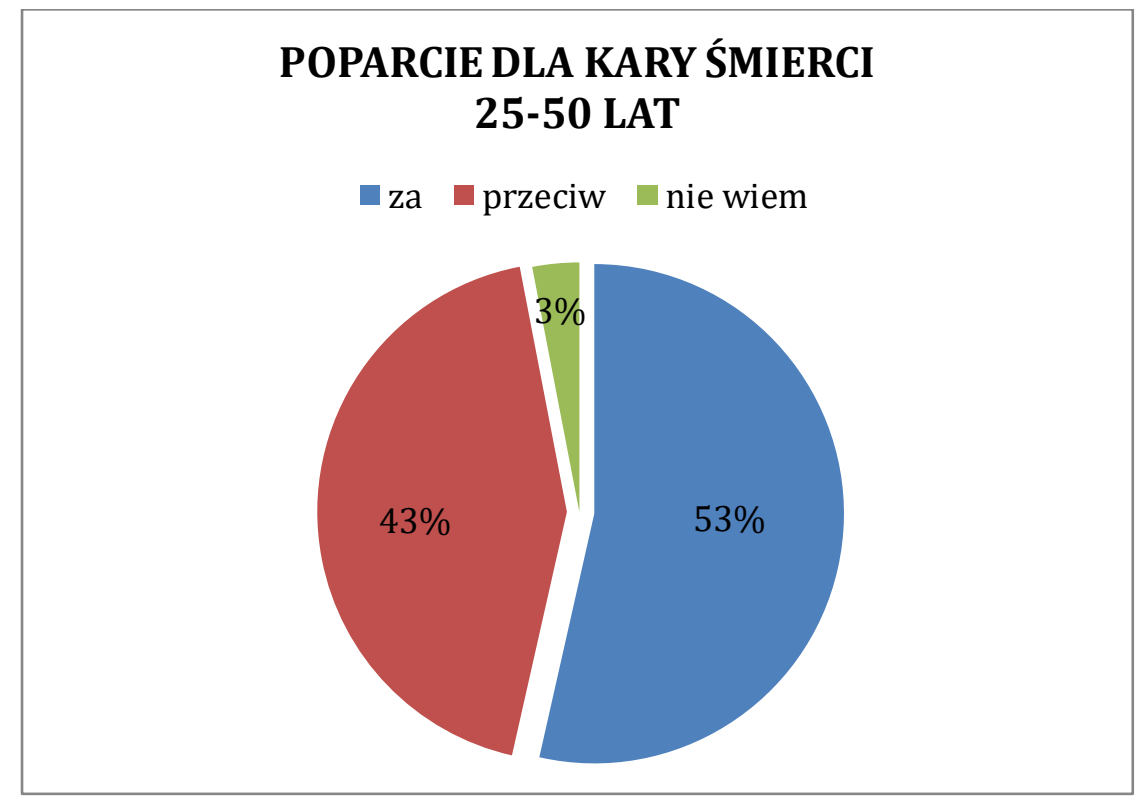

Źródło: badania własne.

Zależności te - choć dosyć podobne w dwóch pierwszych kategoriach wiekowych i bliskie tendencjom ogólnopolskim - ulegają jednak wyraźnej zmianie w ostatnim przedziale wiekowym, skupiającym osoby powyżej 50. roku życia. Wyniki wskazują na diametralne odwrócenie sytuacji, gdyż zaledwie 35\% (11 os.) popiera karę śmierci, z kolei aż 65\% (20 os.) jest jej całkowicie przeciwnych. Badanie potwierdza jedną z hipotez roboczych i zarazem ukazuje słuszność obrania zmiennej niezależnej. Wiek wyraźnie wpływa na stosunek mieszkańców Włocławka i okolic do kary głównej. Warto nadmienić, że 
Karolina Rożko - Kara śmierci jako aktualny dylemat...

spośród 6 osób, które nie podały swojego wieku zdecydowana większość - 83\% (5 os.) to zwolennicy, zaledwie 1 os. (17\%) to przeciwnik.

Wykres 12. Poparcie dla kary śmierci wśród badanych w wieku pow. 50 lat

\section{POPARCIE DLA KARY ŚMIERCI POWYŻEJ 50 LAT}

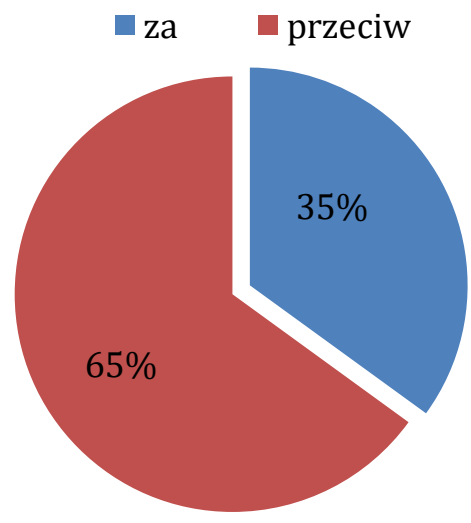

Źródło: badania własne.

Kolejnym czynnikiem pełniącym rolę zmiennej niezależnej jest płeć. Badania pokazują niezbicie, że tendencja do popierania kary śmierci okazuje się wyraźnie wyższa wśród mężczyzn. Na 45 ankietowanych 27 (aż 60\%) poparło karę główną, przeciw było tylko 18 mężczyzn (40\%). Z kolei wśród kobiet podział ten jest bardziej wyrównany. Spośród 75 kobiet 55\% (41 os.) jest za karą śmierci, natomiast $45 \%$ (34 os.) zadeklarowało się jako przeciwniczki tej kary.

Wyniki te potwierdzają słuszność kolejnej hipotezy - płeć stanowi istotną zmienną niezależną różnicującą opinie w tym zakresie. 
Wykres 13. Poparcie dla kary śmierci wśród mężczyzn

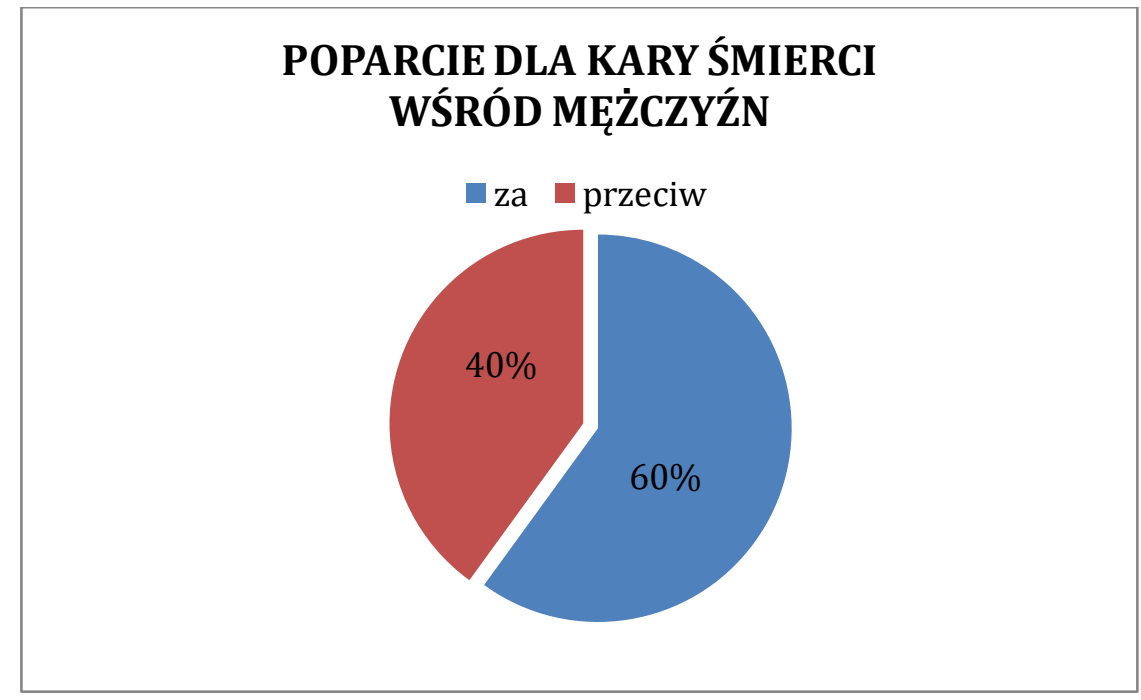

Źródło: badania własne.

Wykres 14. Poparcie dla kary śmierci wśród kobiet

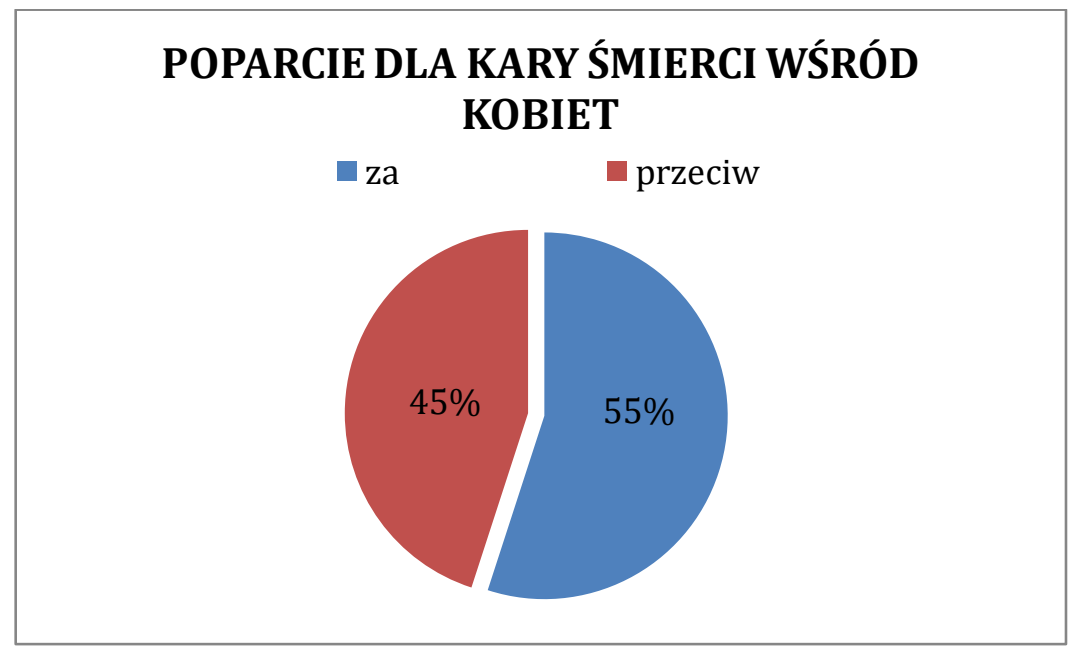

Źródło: badania własne. 
Karolina Rożko - Kara śmierci jako aktualny dylemat...

Poddano analizie także miejsce zamieszkania badanych. 70 respondentów wskazało miasto jako swoje środowisko życia. Wśród nich tendencja okazała się odwrotna względem ogólnych wyników ankiety i danych ogólnopolskich. Większość mieszkańców miasta była przeciwna karze śmierci - 39 osób (56\%), zaś 31 osób (44\%) poparło ją.

Wykres 15. Poparcie dla kary śmierci wśród mieszkańców miasta

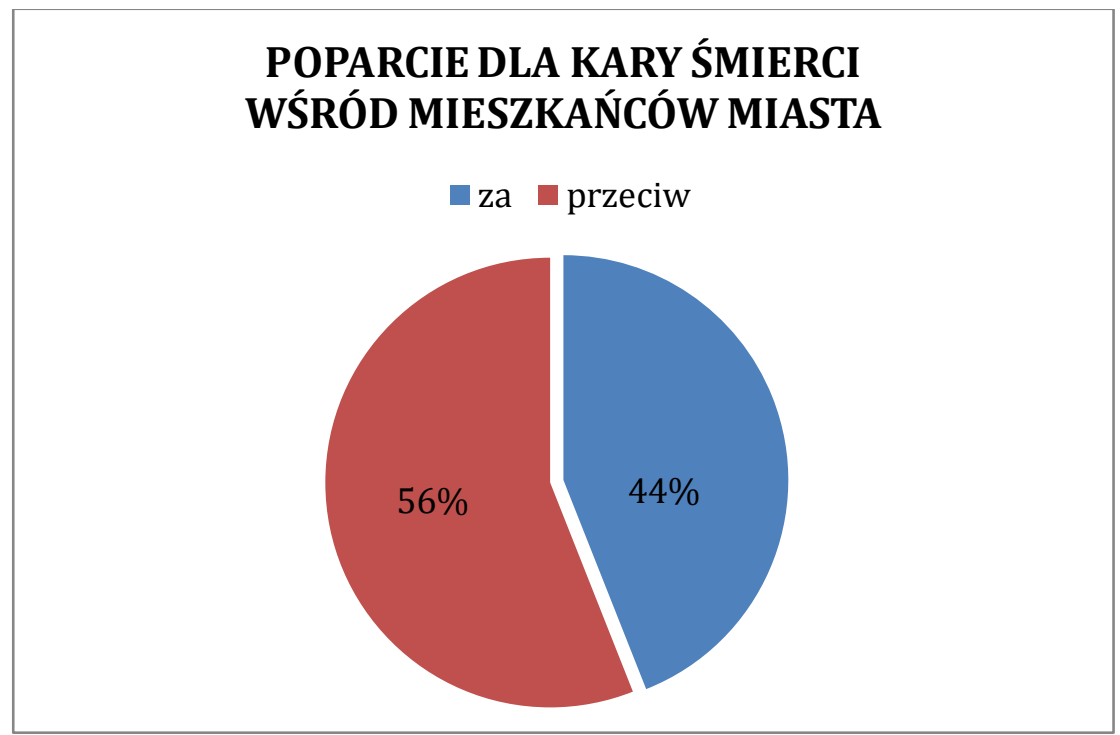

Źródło: badania własne.

Wyraźnym przeciwieństwem są dane zebrane wśród respondentów mieszkających na wsi, gdzie tendencja ponownie wykazuje odwrotną sytuację. Na 44 badanych 28 osób (aż 64\%) opowiedziało się za słusznością przywrócenia kary śmierci. Przeciwko niej było zaledwie 15 osób, co stanowi 34\%. Jedna osoba (2\%) nie odpowiedziała na zasadnicze pytanie. Spośród 11 ankietowanych, którzy nie ujawnili swojego miejsca zamieszkania, 10 osób (91\%) opowiedziało się za karą główną. 
Wykres 16. Poparcie dla kary śmierci wśród mieszkańców wsi

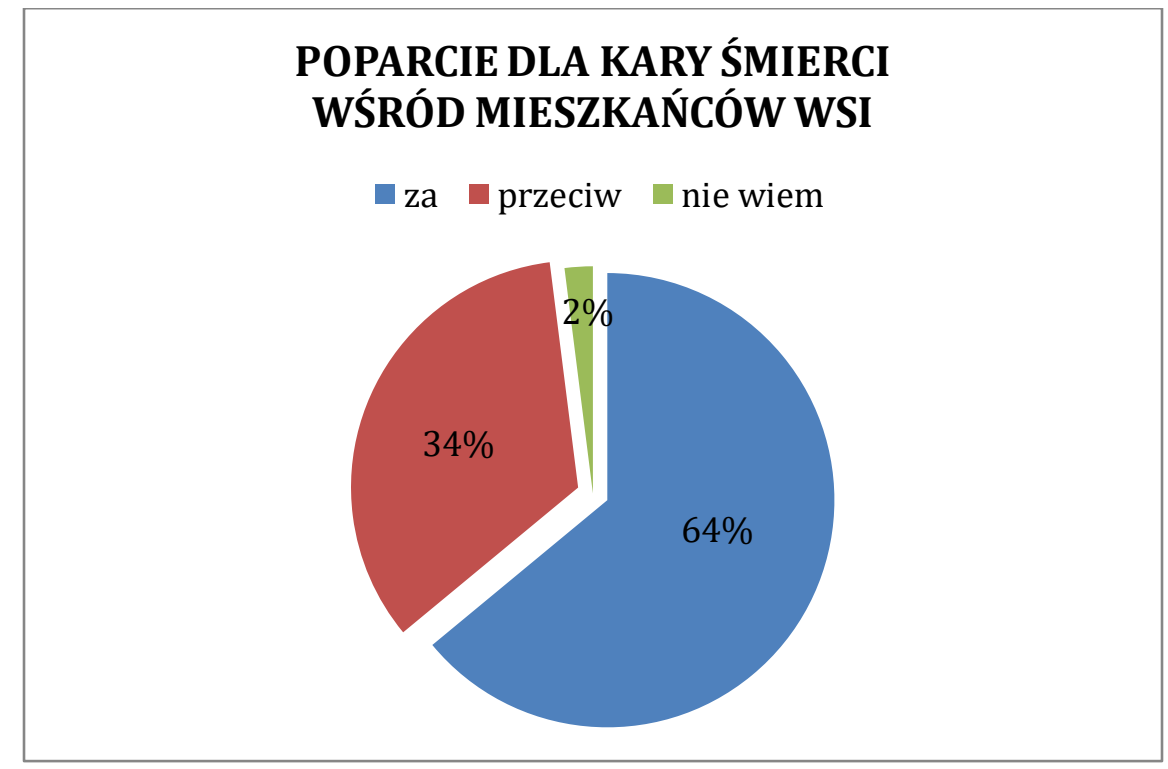

Źródło: badania własne.

Równie ważnym czynnikiem okazuje się być wykształcenie, które wyraźnie koreluje z poglądami ankietowanych na temat kary śmierci. 3 osoby posiadające wykształcenie podstawowe okazały się w przeważającej mierze zwolennikami kary śmierci - 67\% „za”, 33\% „przeciw".

Inaczej przedstawiają się wyniki badanych $\mathrm{z}$ wykształceniem gimnazjalnym. W tym wypadku tendencja okazuje się porównywalna z wynikami zbiorczymi - 54\% (14 os.) zadeklarowało poparcie dla kwestii spornej, 46\% (12 os.) było przeciwnych. 
Karolina Rożko - Kara śmierci jako aktualny dylemat...

Wykres 17. Poparcie dla kary śmierci wśród badanych z wykształceniem podstawowym

\section{POPARCIE DLA KARY ŚMIERCI- WYKSZTAŁCENIE PODSTAWOWE}

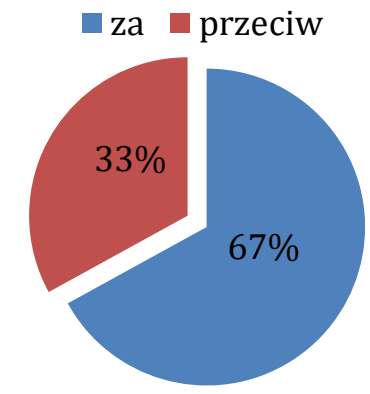

Źródło: badania własne.

Wykres 18. Poparcie dla kary śmierci wśród osób z wykształceniem gimnazjalnym

\section{POPARCIE DLA KARY ŚMIERCI- WYKSZTAŁCENIE GIMNAZJALNE}

za przeciw

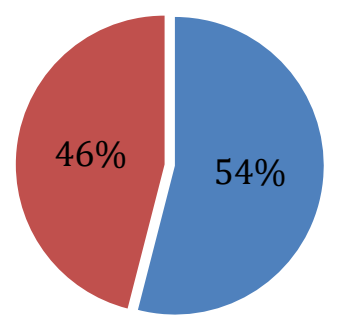

Źródło: badania własne. 
Z kolei respondenci posiadający wykształcenie średnie okazują się być bardziej restrykcyjni w swych poglądach, w większej mierze popierając karę główną. 29 osób (62\%) okazało się jej zwolennikami, 17 osób (36\%) przeciwnikami, 1 osoba (2\%) nie wskazała żadnej odpowiedzi.

Wykres 19. Poparcie dla kary śmierci wśród osób z wykształceniem średnim

\section{POPARCIE DLA KARY ŚMIERCI- WYKSZTALCENIE ŚREDNIE}

za przeciw $\square$ nie wiem

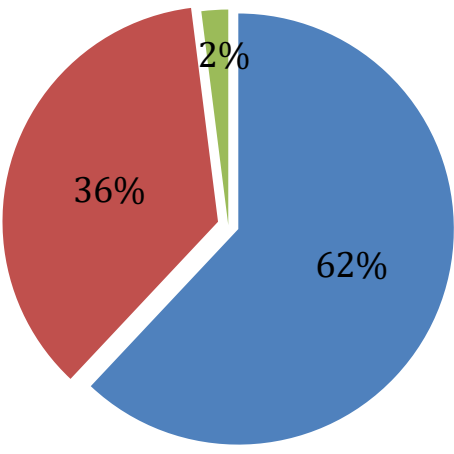

Źródło: badania własne.

Respondenci posiadający wykształcenie wyższe ponownie wykazali poglądy zbliżone do wyników innych badań - 53\% (25 os.) poparło karę główną, 22 osoby (47\%) się jej sprzeciwiło. 2 ankietowanych w ogóle nie podało swoje wykształcenia, jednocześnie popierając karę śmierci. Wyniki te ukazują niezbicie, że wykształcenie jest zmienną niezależną i ma wpływ na poglądy dotyczące kary śmierci. 
Karolina Rożko - Kara śmierci jako aktualny dylemat...

Wykres 20. Poparcie dla kary śmierci wśród osób z wykształceniem wyższym

\section{POPARCIE DLA KARY ŚMIERCI- WYKSZTAŁCENIE WYŻSZE}

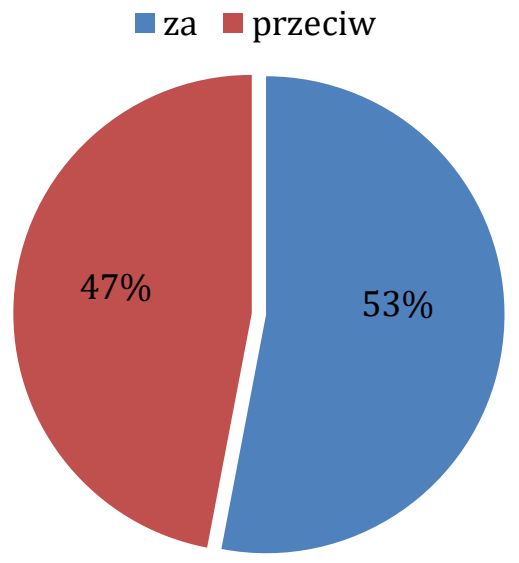

Źródło: badania własne.

Również religijność w świetle wyników ankiety okazuje się mieć istotny wpływ na poglądy mieszkańców Włocławka i okolic w kwestii kary śmierci. Spośród grupy 90 ankietowanych, którzy zadeklarowali się jako osoby wierzące (w przeważającej mierze wyznanie katolickie) nieznaczna większość - 47 osób, co stanowi 52\% - opowiedziała się za karą główną. Przeciwników było mniej - 42 badanych, co stanowi 47\%. Jedna osoba wierząca (1\%) nie sprecyzowała swojego podejścia do sprawdzanej kwestii. Tendencje te są bliskie z trendem ogólnym.

Inaczej rzecz się ma w wypadku respondentów, którzy przedstawiają się jako niewierzący. W gronie 33 osób o takim światopoglądzie ujawniło się 20 zwolenników przywrócenia kary śmierci, co stanowi 61\% - odsetek znacząco wyższy niż w wypadku grupy wierzących ankietowanych, przypominający wyniki najbardziej „radykalne”, porównywalne ze zdaniem mieszkańców wsi, osób z wykształceniem 
podstawowym i licealnym. Przeciwników kary ostatecznej było też odpowiednio mniej, zaledwie 13, co stanowi 39\%.

Wykres 21. Poparcie dla kary śmierci wśród osób wierzących

\section{POPARCIE DLA KARY ŚMIERCI WŚRÓD OSÓB WIERZĄCYCH}

za przeciw nie wiem

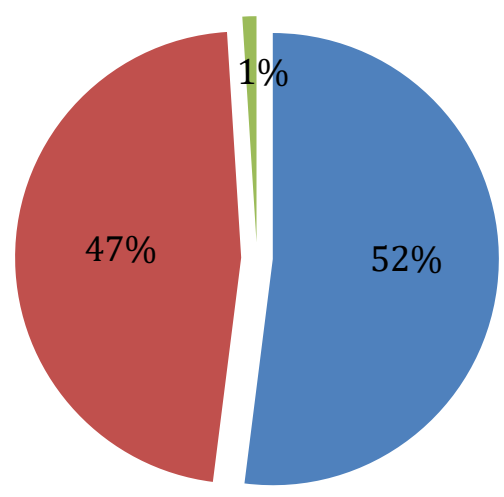

Źródło: badania własne.

Dodajmy, że dwie osoby, które nie zadeklarowały swojego wyznania, również poparły przywrócenie kary śmierci.

W świetle zaprezentowanych danych można uznać, co też nie powinno $\mathrm{w}$ zasadzie zaskakiwać, że religijność $\mathrm{w}$ istotnym stopniu przekłada się na stosunek do ludzkiego życia, a co za tym idzie także do kary śmierci. Zapewne osobną kwestią pozostanie, na ile ludzie wierzący stosują w praktyce zasady wyznawanej religii. 
Karolina Rożko - Kara śmierci jako aktualny dylemat...

Wykres 22. Poparcie dla kary śmierci wśród osób niewierzących

\section{POPARCIE DLA KARY ŚMIERCI WŚRÓD OSÓB NIEWIERZĄCYCH}

za przeciw

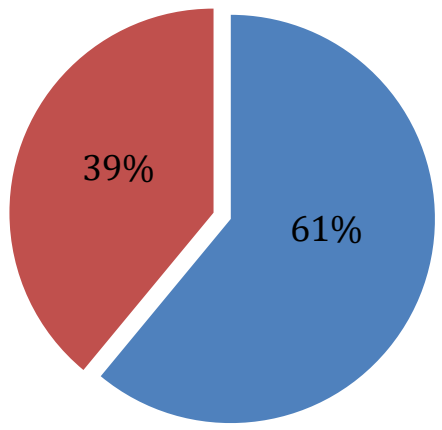

Źródło: badania własne.

Podsumowując zaprezentowane wyniki badań, można stwierdzić, że kara śmierci ciągle wywołuje kontrowersje, przynajmniej wśród badanej społeczności Włocławka i okolic. Ważnym czynnikiem różnicującym opinie badanych staja się takie zmienne, jak: wiek, religijność, wykształcenie, płeć, czy miejsce zamieszkania. Przede wszystkim należy podkreślić, że kara śmierci ma najwięcej zwolenników wśród mężczyzn, zamieszkałych na wsi, posiadających wykształcenie podstawowe lub średnie.

Z drugiej strony statystyczny przeciwnik kary śmierci to kobieta, zamieszkująca w mieście, posiadającą wyższe wykształcenie, w wieku powyżej 50 lat.

Można też wyodrębnić opinie grupy młodzieży szkół średnich i studentów. Wyraźnie potwierdzają one widoczną w Polsce tendencję do radykalizacji poglądów tej grupy wiekowej na karę śmierci. Młodzież - czego dowodzą chociażby wyniki wyborów i sondaże po- 
parcia partii politycznych - w większej liczbie popiera idee prawicowe lub skrajnie prawicowe, co wyraża się między innymi w poparciu dla surowych kar kryminalnych, w tym - dla kary głównej.

Wyraźnie przeciwni karze śmierci okazują się z jednej strony ludzi głęboko wierzący, lub też - z drugiej strony - posiadający wyższe wykształcenie, mający powyżej 50 lat i mieszkający w środowisku miejskim.

Mimo występującej zależności między religijnością a postawami wobec kary śmierci, przeprowadzone badania pokazały, że ten czynnik nie jest decydujący. Idąc dalej tym tropem warto więc zastanowić się nad charakterem zgłaszanej w badaniach religijności mieszkańców Włocławka i okolic.

Ciekawym wątkiem badawczym okazuje się stosunek nie tylko do samej kary śmierci, ale także do form jej egzekucji. 2/3 badanych (67\%) wybiera najbardziej humanitarną z nich, czyli zastrzyk z trucizną. Pozwala to uznać, że spora część społeczności włocławskiej przejawia humanitaryzm w podejściu do wymierzania kary głównej.

Dyskusyjną i zarazem interesującą kwestią okazał się stosunek do wieku odpowiedzialności karnej - zdecydowana większość uważa, że egzekucje powinny być przeprowadzane już na osiemnastolatkach, co pośrednio wskazuje na niski poziom zaufania do systemu resocjalizacji. Podkreślić też warto, że co dziesiąty badany twierdzi, że karą śmierci należałoby objąć już trzynastolatków.

Wyniki przeprowadzonych i przedstawionych tutaj badań zdają się dowodzić, że kara śmierci ciągle jest tematem dyskusyjnym i dzielącym Polaków. wskazuje to na ciągłą potrzebę prowadzenia monitoringu postaw $\mathrm{w}$ tym zakresie, jak też podejmowania stałej debaty publicznej mającej na celu poszerzenie wiedzy i świadomości karnoprawnej obywateli. 
Karolina Rożko - Kara śmierci jako aktualny dylemat...

\section{Bibliografia:}

Bartula P., Kara śmierci - powracający dylemat, Kraków 1998.

Bartusiak B., Kara śmierci w świetle sporu o racjonalizację kary, Warszawa 2011.

Beccaria C., O przestępstwach i karach, (przeł.) E. S. Rappaport, Warszawa 1959.

Burszta W. J., Antropologia kultury. Tematy, teorie, interpretacje, Poznań 1998.

Foucault M., Nadzorować i karać. Narodziny więzienia, (przeł.) T. Komendant, Warszawa 2009.

Grześkowiak A., Kara śmierci w polskim prawie karnym, Toruń 1982.

Haag E. van den, Deterrence and Uncertainty, [in:] T. A. Mapprs, J. S. Zembaty (ed.), Social Ethics. Morality and Social Policy. An Anthology, New York 1987.

Hernik-Pikulska B., Kara śmierci. Studium socjologiczne, Kraków 2006.

Katana K., Pozytywne przykłady (wywiad z Lidią Olejnik), [w:] H. Bortnowska, M. Sopyło (red.), Przeciw karze śmierci, Warszawa 2011.

Łobocki M., Metody badań pedagogicznych, Warszawa 1982.

Łobocki M., Wprowadzenie do metodologii badań pedagogicznych, Kraków 2009.

Machinek M. MSF, Śmierć $w$ dyspozycji człowieka. Teologia moralna wobec problemów etycznych u kresu życia ludzkiego, Olsztyn 2001.

Mounier E., Ogólna idea osoby, [w:] J. Pawlak (red.), Kierunki filozofii współczesnej, cz. I, Toruń 1995.

Pilch T., Zasady badań pedagogicznych, Warszawa 1995.

Seitz T., The Killing Chair, „North Carolina Historical Review” 2004, nr 81.

Stępniewska K., Pampersy też sq̨ resocjalizacją (wywiad z M. Łagodzińskim), [w:] H. Bortnowska, M. Sopyło (red.), Przeciw karze śmierci, Warszawa 2011.

Ślipko T. SJ, Kara śmierci z teologicznego i filozoficznego punktu widzenia, Kraków 2000.

Warylewski J., Kara. Podstawy filozoficzne i historyczne, Gdańsk 2007. 